\title{
Diretrizes para Autores
}

\section{INSTRUÇÕES AOS AUTORES}

Os trabalhos enviados para publicação devem ser inéditos, em meios impressos e eletrônicos, não sendo permitida sua apresentação simultânea para avaliação em outro periódico. A revista aceita para publicação textos redigidos em português, inglês e espanhol. Os trabalhos aprovados serão publicados no idioma de origem. Não será cobrada nenhuma taxa para submissão, avaliação, edição e publicação dos artigos.

Se o artigo é versão decorrente de outra já publicada pelo autor, é necessário informar tal situação ao Editor no momento da submissão à Roteiro.

Recomenda-se fortemente aos autores a observação quanto à ética em sua pesquisa e na decorrência da publicação de seu artigo, verificando questões como plágio e autoplágio as quais prejudicam intensamente a qualidade e o padrão observado pela Roteiro.

A fim de se resguardar como publicação científica séria e reconhecida que é, a Revista reserva-se o direito de excluir o artigo e banir do periódico o autor responsável pela publicação, quando nesta for provado:

a) Plágio: utilizar-se de resultados, conclusões ou informações de outros autores e citá-los sem a devida referência, utilizando os dados como se fossem seus;

b) Autoplágio: utilizar materiais já publicados de sua autoria sem referenciá-los adequadamente;

c) Falsificação: manipular, inventar ou alterar dados da pesquisa, locais ou resultados conforme melhor lhe convier. 
Cada artigo poderá ter no máximo três (3) autores que, preferencialmente, participem de grupos de pesquisas. Exige-se que, pelo menos, um dos autores tenha o título de doutor.

$\bigcirc$ artigo, resultante de dissertação de mestrado e de tese de doutorado, poderá ter, no máximo, dois (2) autores.

A apreciação do artigo pelos pareceristas reside na consistência do resumo (apresentando, necessariamente, objetivo, temática, procedimento metodológico e resultados); consistência interna do trabalho (com relação ao objetivo, referencial teórico, procedimento metodológico e aos resultados); consistência do título (com relação ao conhecimento produzido);qualidade do conhecimento educacional produzido (com relação à densidade analítica, evidências ou provas das afirmações apresentadas e ideias conclusivo-analíticas); relevância científica (com relação aos padrões de uma pesquisa científica); originalidade do trabalho (com relação aos avanços da área de Educação) e adequação da escrita à norma culta da língua.

A Roteiro reserva-se ao direito de não publicar artigos e resenhas de mesma autoria (ou em coautoria) em intervalos inferiores a dois anos.

\section{APRESENTAÇÃO FORMAL DOS ORIGIINAIS:}

Quando da submissão do manuscrito, deverá ser submetido também um documento suplementar contendo os seguintes dados:

(i) título e subtítulo do trabalho;

(ii) nome(s) do(s) autor(es);

(iii) endereço residencial e eletrônico, telefone; titulação e

(iv) vínculo institucional (nome da instituição, cidade, estado e país).

Os originais deverão ser redigidos na ortografia oficial e digitados em processador de texto Word for Windows, em fonte Times New Roman, tamanho 
12, espaço 1,5, em folha formato A4, margens superior e esquerda $3 \mathrm{~cm}$, margens inferior e direita $2 \mathrm{~cm}$. Ilustrações, tabelas, notas e citações diretas em recuo, fonte tamanho 10, entradas de parágrafo, 1,25, a partir da margem. $\bigcirc$ texto deve ser justificado, exceto as referências, que são alinhadas à margem esquerda, com espaço 1,0 entre uma e outra. As páginas deverão ser numeradas à margem superior direita, a partir da folha de rosto. Os artigos deverão conter, no mínimo 15 e no máximo 25 páginas, incluindo resumos, notas e referências. Recomendase aos autores que submetam o texto à revisão ortográfica e gramatical antes de encaminhá-lo à Roteiro.

No preparo do original, deverá ser observada a seguinte estrutura:

a) Título e subtítulo do texto não devem ultrapassar 15 palavras. Deve figurar na página de abertura do texto;

b) Título e subtítulo versados para o inglês e para o espanhol;

c) Resumo e palavras-chave: o resumo deve conter de 100 a 250 palavras. As palavras-chave, que identificam o conteúdo do artigo, devem ser de, no máximo cinco (05), separadas por ponto e iniciadas por letra maiúscula. Para a redação e estilo do resumo, observar as orientações da NBR 6028, da Associação Brasileira de Normas Técnicas (ABNT).

d) Abstract, Keywords;

e) Resumen, Palabras clave;

f) Corpo do texto, ao longo do qual não deve haver qualquer identificação autoral, contendo os seguintes elementos textuais: introdução, desenvolvimento e conclusão;

g) Referências: devem obedecer às normas da Associação Brasileira de Normas Técnicas, NBR 6023 vigente, sendo ordenadas alfabeticamente pelo sobrenome do primeiro autor. No caso do prenome e nome do meio, devem ser registradas apenas as letras iniciais. Nas referências de até três autores, todos poderão ser citados, separados por ponto e vírgula. Nas referências com 
mais de três autores, citar somente o primeiro autor, seguido da expressão et al. A exatidão das referências constantes na listagem e a correta citação de seus dados no texto são de responsabilidade do(s) autor(es) do trabalho.

Notas de rodapé: quando existirem, devem ser breves e numeradas sequencialmente. Não é permitido o uso de notas bibliográficas. Para isso, deve-se utilizar as citações no texto. A identificação das referências no corpo do trabalho deve ser feita com a indicação do(s) nome(s) do(s) autor(es), ano de publicação e paginação. Ex.: (OLIVEIRA, 2004, p. 65);

Tabelas e figuras: devem ser numeradas, consecutivamente, com algarismos arábicos, na ordem em que forem incluídas no texto e encabeçadas pelo título. Na montagem das tabelas, recomenda-se seguir as "Normas de Apresentação Tabular", publicadas pelo IBGE. As ilustrações devem ser designadas conforme sua especificação, se fotografias, desenhos, gráficos, etc., apresentando, necessariamente, qualidade de resolução (a partir de 300 dpis) para sua reprodução direta.

\section{IMPORTANTE:}

- Na lista de referências devem ser citadas todas e somente as que foram citadas internamente no artigo. As referências de suporte não devem ser citadas na lista.

- Ainda, observar se todas as que foram citadas constam na lista.

\section{ALGUNS EXEMPLOS DE REFERÊNCIAS:}




\section{Livro (um autor)}

GAMBOA, S. S. Pesquisa em educação: métodos e epistemologias. 2. ed. Chapecó: Argos, 2012.

\section{Livro (dois autores)}

APPLE, M. W.; BURAS, K. L. (Org.). Currículo, poder e lutas educacionais: com a palavra, os subalternos. Porto Alegre: Artmed, 2008.

\section{Livro em formato eletrônico}

BERTOCHE, G. A objetividade da ciência na filosofia de Bachelard. Rio de Janeiro: Edição do Autor, 2006. Disponível em: <http://wwww.ebooksbrasil. org/adobebook/objbachelard.pdf>. Acesso em: 18 nov. 2008.

\section{Capítulos de livros}

DAMIS, O. T. Formação pedagógica do profissional da educação no Brasil: uma perspectiva de análise. In: VEIGA, I. P. A.; AMARAL, A. L. (Org.). Formação de professores: políticas e debates. 2. ed. Campinas: Papirus, 2002. p. 97-130.

\section{Artigo de periódico}

OLIVEIRA, R. P.; ARAÚJO, G. Qualidade do ensino: uma nova dimensão da luta e o direito à educação. Revista Brasileira de Educação, Rio de Janeiro, n. 28, p. 5-23, jan./abr. 2005.

\section{Artigo de periódico (com mais de três autores)}

MASINI, E. F. S. et al. Concepções de professores do ensino superior sobre surdocegueira: estudo exploratório com quatro docentes.Revista Brasileira de Estudos Pedagógicos, Brasília, DF, v. 28, n. 22, p. 556-573, set./dez. 2007. 


\section{Artigo de periódico (formato eletrônico)}

OLIVEIRA, O. V. de; MIRANDA, C. Multiculturalismo crítico, relações raciais e política curricular: a questão do hibridismo na Escola Sarã. Revista Brasileira de Educação, Campinas, n. 25, p. 67-81, jan./abr. 2004. Disponível em: <http://www.anped.org.br/rbe>. Acesso em: 18 nov. 2008.

\section{Teses}

MOURA, R. R. Estrutura de oportunidades políticas e aprendizado democrático: o associativismo de bairro em Blumenau (1994-2009). Tese (Doutorado em Educação) - Universidade Federal de Santa Catarina, Florianópolis, 2009.

\section{Artigo assinado (jornal)}

DiMENSTEIN, G. Escola da vida. Folha de S. Paulo, São Paulo, p. 2, 14 jul. 2002.

\section{Artigo não assinado (jornal)}

EXPANSÃO dos canaviais é acompanhada por exploração de trabalho. Brasil de Fato, São Paulo, p. 5, 13-19 nov. 2008.

\section{Decretos, leis}

BRASIL, Decreto n. 2.134, de 24 de janeiro de 1997. Regulamenta o art. 23 da Lei n. 8.159, de 8 de janeiro de 1991, que dispõe sobre a categoria dos documentos públicos sigilosos e o acesso a ele, e dá outras providências.

Diário Oficial da República Federativa do Brasil, DF, n. 18, p. 1435-1436, jan. 1997. Seçãol. 


\section{Constituição Federal}

BRASIL. Constituição (1998). Constituição da República Federativa do Brasil. Brasília, DF: Senado Federal, 1998.

\section{Relatório Final}

UNIVERSIDADE DE BRASÍLIA. Relatório de atividades 1999-1993. Brasília, DF, 1993.

\section{Gravação de vídeo}

COM LICENÇA, eu vou à luta. Direção: Luis Farias. Produção: Mauro Farias, Rio de Janeiro: Embrafilme, Produções Cinematográficas R. F. Farias Ltda., Time de Cinema, 1986. I DVD.

\section{CD-Rom}

DEPARTAMENTO INTERSINDICAL DE ESTATÍSTICAS E ESTUDOS SOCIOECONÔMICOS. Anuário dos trabalhadores 2006. São Paulo: Dieese, 2006. 1 CD-ROM.

\section{Trabalho apresentado em evento}

CASTANHO, M. E.; CASTANHO, S. E. M. Contribuição ao estudo da história da didática no Brasil. In. REUNIÃO ANUAL DA ANPED, 31 . 2008, Caxambu. Anais... Rio de Janeiro: Anped, 2008, v. 1.

Resenhas: não devem ultrapassar duas mil palavras. É indispensável indicação da referência completa da obra resenhada ou comentada. A digitação e a formatação devem obedecer à mesma orientação dada aos artigos. Não é permitido inserir tabelas e/ou ilustrações. Somente serão aceitas resenhas de obras inteiras. Não se aceitam resenhas de capítulos ou partes de livro. As resenhas devem priorizar obras publicadas até dois anos de sua $1^{a}$ edição e apresentar a seguinte sequência: Título; Nome do resenhista; Instituição a que pertence; Referência completa da obra; Texto. As resenhas podem ser enviadas 
em inglês, português ou espanhol. Aceitam-se resenhas de mestrandos e doutorandos.

Entrevistas: serão publicadas a convite do Editor e direcionadas a pesquisadores de reconhecida competência científica nacional e/ou internacional.

Dossiê: verificar informações específicas.

\section{ORIENTAÇÕES PARA SUBMISSÃO DOS TRABALHOS:}

A Roteiro opera exclusivamente pelo Sistema Eletrônico de Editoração de Revistas. $\bigcirc$ processo de captação e arbitragem dos textos passa, necessariamente, por uma plataforma on-line, onde os autores poderão se cadastrar e submeter seus trabalhos para apreciação do Comitê Editorial, podendo, inclusive, acompanhar os trâmites editoriais de seu texto.

Para se cadastrar no sistema, é necessário acessar o endereço abaixo e, depois, seguir as orientações para submissão de trabalhos à Roteiro.

Endereço de acesso: http://editora.unoesc.edu.br/index.php/ roteiro/about/submissions\# onlineSubmissions

Antes do processo de submissão, recomenda-se aos autores consultar números anteriores da Roteiro e rever atentamente o trabalho a fim de verificar se este respeita as normas e critérios de aceitação da Revista. 


\section{NORMAS PARA SUBMISSÃO DE DOSSIÊS}

1) Para compor um dossiê, são necessários, no mínimo, oito textos de autores de diferentes instituições nacionais, inclusive em termos de abrangência territorial, e, ao menos, dois textos de autores de instituições estrangeiras. Os textos devem tratar especificamente do tema do referido dossiê. Considerando que nem todos os textos submetidos podem ser aprovados, há necessidade de reunir um número maior de textos do que o previsto para publicação, a fim de assegurar a publicação sob forma de dossiê.

2) Os proponentes-organizadores do dossiê devem ser professores e/ou pesquisadores de instituições de ensino superior ou de pesquisa do Brasil ou do exterior, envolvidos com a área temática em questão. $\bigcirc$ proponente principal deve possuir, necessariamente, título de doutor.

3) Os proponentes-organizadores figurarão na publicação como organizadores, cabendo-lhes a apresentação do dossiê. Os proponentes-organizadores poderão ser autor ou coautor de, no máximo, um artigo que compõe o dossiê.

4) Os proponentes-organizadores devem cumprir os prazos estabelecidos pela Roteiro e responsabilizar-se pela guarda e sigilo necessários ao processo de avaliação por pares.

5) Os artigos constantes da proposta devem ser encaminhados pelo próprio autor ou responsável, pelo Sistema SEER da Revista, que inclui preenchimento do cadastro do autor e coautores. Os textos devem ser formatados segundo as normas da Revista.

6) Os artigos serão avaliados individualmente, pelos avaliadores ad hoc da Roteiro.

7) Artigos recusados quanto à forma ou quanto ao mérito não serão publicados, mesmo que constituam parte da proposta do dossiê. 
8) Caso trinta por cento ou mais dos artigos sejam recusados, a seção será reavaliada pela Editoria, podendo ser recusada nessa etapa, e os textos aprovados constarem como de demanda contínua, se os autores assim o desejarem.

9) Uma vez aceito para publicação, o trabalho é submetido a uma revisão de linguagem e a uma normalização. $\bigcirc$ trabalho é encaminhado ao autor com as sugestões de correções e adequações, para que seja finalmente encaminhado pela Editoria para a publicação.

10) Uma vez que o conjunto de artigos tenha passado pelos trâmites de avaliação e revisão da Roteiro, e assim seja considerado pronto para publicação, a Editoria determinará qual o volume e o respectivo número no qual o dossiê será publicado.

11) Ao submeter o artigo e tê-lo aprovado, os autores concordam em ceder, sem remuneração, os seguintes direitos à Roteiro: os direitos de primeira publicação e a permissão para que a Roteiro redistribua esse artigo e seus metadados aos serviços de indexação e referência que seus editores julguem apropriado.

12) $\bigcirc$ mérito, as concepções, ideias, opiniões e posições de qualquer ordem contidas nos artigos são de inteira responsabilidade dos respectivos autores.

13) Enquanto tramitar na Roteiro, a proposta de dossiê não poderá ser encaminhada a nenhuma outra revista.

14) As exceções ao fluxo regular serão avaliadas pela Comissão Editorial.

\section{INSTRUCTIONS TO AUTHORS}

Roteiro is a scientific biannual periodic, linked to the Post-graduation Program - Masters in Education - of Universidade do Oeste de Santa Catarina 
(Unoesc). It has as scope the publishing of original scientific/academic works, the stimulus to the research and to the debate in the Education area.

The works sent to publish must be unpublished, in electronic and printed media, and it is not allowed its simultaneous presentation to the evaluation in other periodic. The magazine accepts texts in Portuguese and Spanish. The approved works will be publish in the original idiom.

\section{Originals formal presentation:}

The originals should be written according to the official spelling rules and typed with the use of the Word for Windows program, Times New Roman, size 12, space 1,5, in A4 format, top and left margin $3 \mathrm{~cm}$, bottom and right margin $2 \mathrm{~cm}$. Illustrations, charts, notes and direct quotes indented, font size 10, paragraph, 1,25 from the margin. The text must be justified, except the references, which are aligned to the left margin, with space 1,0 between one and the other. The pages must be numbered to the right top margin, starting from the cover page. The article must have 15 to 25 pages, including abstracts, notes and bibliographies. It is strongly recommended that the authors submit the text to an orthographic and grammatical review before sending it to Roteiro.

In the preparation of the original, it is important to check the following structure:

a) Title and subtitle (up to two lines): avoid long titles. The title must be in the opening page, separated by colon and in the text language;

b) Abstract and keywords: the abstract must contain between 550 to 800 characters (considering the spaces). The keywords, which identify the content of the article, must be maximum five (05), separated by period and begun by capital letter. To the writing and the style of the abstract, it is necessary to observe the 
orientation of NBR 6028, from Brazilian Association of Technical Norms (ABNT). The abstracts, the title and the keywords must be presented also in foreign language (English) and keep the same characteristics of the Portuguese version.

c) Body of the text. Throughout it, there should not be author identification, containing the following textual elements: introduction, development and conclusion.

d) References: they must obey the rules of Brazilian Association of Technical Norms (ABNT), alphabetically organized by the first author's last name. About the name and the middle name, it is necessary to register only the first letters. In the references up to three authors, all can be cited, separated by semi-colon. In the references with more than three authors, it must be cited only the first author followed by the expression et al. The accuracy of the references contained in the list and the correct citation of their data in the text are the work's author(s)'s responsibility.

\section{Some examples of references:}

\section{Book (one author)}

GAMBOA, S. S. Pesquisa em educação: métodos e epistemologias. 2. ed. Chapecó: Argos, 2012.

\section{Book (two authors)}

APPLE, M. W.; BURAS, K. L. (Org.). Currículo, poder e lutas educacionais: com a palavra, os subalternos. Porto Alegre: Artmed, 2008. 


\section{Book in eletronic format}

BERTOCHE, G. A objetividade da ciência na filosofia de Bachelard. Rio de Janeiro: Edição do Autor, 2006. Disponível em: <http://wwww.ebooksbrasil. org/adobebook/objbachelard.pdf>. Acesso em: 18 nov. 2008.

\section{Chapters of books}

DAMIS, O. T. Formação pedagógica do profissional da educação no Brasil: uma perspectiva de análise. In: VEIGA, I. P. A.; AMARAL, A. L. (Org.). Formação de professores: políticas e debates. 2. ed. Campinas: Papirus, 2002. p. 97-130.

\section{Article of periodic}

OLIVEIRA, R. P.; ARAÚJO, G. Qualidade do ensino: uma nova dimensão da luta e o direito à educação. Revista Brasileira de Educação, Rio de Janeiro, n. 28, p. 5-23, jan./abr. 2005.

\section{Article of periodic (with more than three authors)}

MASINI, E. F. S. et al. Concepções de professores do ensino superior sobre surdocegueira: estudo exploratório com quatro docentes. Revista Brasileira de Estudos Pedagógicos, Brasília, DF, v. 28, n. 22, p. 556-573, set./dez. 2007.

\section{Article of periodic (eletronic format)}

OLIVEIRA, O. V. de; MIRANDA, C. Multiculturalismo crítico, relações raciais e política curricular: a questão do hibridismo na Escola Sarã. Revista Brasileira de Educação, Campinas, n. 25, p. 67-81, jan./abr. 2004. Disponível em: <http://www.anped.org.br/rbe>. Acesso em: 18 nov. 2008.

Thesis 
MOURA, R. R. Estrutura de oportunidades políticas e aprendizado democrático: o associativismo de bairro em Blumenau (1994-2009). Tese (Doutorado em Educação) - Universidade Federal de Santa Catarina, Florianópolis, 2009.

\section{Signed article (newspaper)}

DiMENSTEIN, G. Escola da vida. Folha de S. Paulo, São Paulo, p. 2, 14 jul. 2002.

Not signed article (newspaper)

EXPANSÃO dos canaviais é acompanhada por exploração de trabalho. Brasil de Fato, São Paulo, p. 5, 13-19 nov. 2008.

\section{Decrees, laws}

BRASIL, Decreto n. 2.134, de 24 de janeiro de 1997. Regulamenta o art. 23 da Lei n. 8.159, de 8 de janeiro de 1991, que dispõe sobre a categoria dos documentos públicos sigilosos e o acesso a ele, e dá outras providências. Diário Oficial da República Federativa do Brasil, DF, n. 18, p. 1435-1436, jan. 1997. Seçãol.

\section{Federal Constitution}

BRASIL. Constituição (1998). Constituição da República Federativa do Brasil. Brasília, DF: Senado Federal, 1998.

\section{Final report}


UNIVERSIDADE DE BRASÍLIA. Relatório de atividades 1999-1993. Brasília, DF, 1993.

\section{Vídeo recording}

COM LICENÇA, eu vou à luta. Direção: Luis Farias. Produção: Mauro Farias, Rio de Janeiro: Embrafilme, Produções Cinematográficas R. F. Farias Ltda., Time de Cinema, 1986. 1 DVD.

\section{CD-Rom}

DEPARTAMENTO INTERSINDICAL DE ESTATÍSTICAS E ESTUDOS SOCIOECONÔMICOS. Anuário dos trabalhadores 2006. São Paulo: Dieese, 2006. 1 CD-ROM.

\section{Work presented in events}

CASTANHO, M. E.; CASTANHO, S. E. M. Contribuição ao estudo da história da didática no Brasil. In. REUNIÃO ANUAL DA ANPED, 31. 2008, Caxambu. Anais... Rio de Janeiro: Anped, 2008, v. 1.

Notes: when there are notes, they must be numbered sequentially and put in the end of the text. It is not allowed the use of bibliographic notes. In this regard, it must be used the quotes in the text. The identification of the references in the body of the work should be done with the indication of the author(s)'s names, year of publishing and page. Ex: (OLIVEIRA, 2004, p. 65).

For chars and illustrations (photographs, maps, graphics, boards, flowcharts, organograms, diagram, schemes and others), it is necessary that 
the original files are sent, as well, in digital file, separately. The scanned images must have resolution of 300 dpi. The illustrations and charts must be numbered according to their corresponding references in the body of the text, and the titles, written without abbreviation, with the reference font size 10 and simple line space. Avoid the use of words like "below", "above" to refer to charts and illustrations.

Author(s)'s identification page, containing the following data: (i) title and subtitle of the work; (ii) author(s)'s name(s); (iii) home address and electronic address, telephone; qualification and (iv) institutional affiliation (name of the institution, city, state and country).

Reviews: they cannot be longer than two thousand words. It is essential the indication of the complete reference of the work reviewed or commented. The typing and the formatting must obey the same orientation given to the articles. It is not permitted the insertion of charts and/or illustrations. It will only be accepted reviews from complete works. It is not accepted reviews of chapters or parts of the book. The reviews should prioritize works published up to two years from its first edition and present the following sequence: Title; Name of the reviewer; Institution where he/she belongs to; Complete references of the work (Title. City: Publisher, Year. Number of pages. The author's last name and name); Text.

Interviews: they will be published due to an invitation of the Editor and directed to researchers of recognized national and/or international scientific competence.

\section{ORIENTATIONS TO THE SUBMISSION OF THE WORKS:}

Roteiro works exclusively by the Electronic System of Magazine Publishing. The collection and the arbitrage process goes, necessarily through 
an on-line platform, where the authors will be able to register and submit their articles to the evaluation of the Editorial Counsel, being able, also, to follow the publishing procedures of their text.

To register in the system, it is necessary to access the following website and, after, follow the orientation to work submission to Roteiro. http://editora. unoesc.edu.br/index.php/roteiro/about/submissions\# onlineSubmissions

Before the submission process, it is recommended to the Authors to consult Roteiro's preview numbers and carefully review the work, due to verify it this one respects the norms and criteria of the Magazine's acceptance.

\section{Important}

Roteiro is published in electronic format (PDF), available by Internet in the Magazine's website and/or in the indexer(s)' website(s). Roteiro will allow access to the articles, the reviews and the other texts, not authorizing any commercialization and/or data alteration. Thus, the author(s) is (are) aware of the cession of their publishing copyright.

For the authors' knowledge, we inform that the edited material (originals, drafts, content) will remain stored on Publisher Unoesc for one year, after being published, according to the Editorial Policy, and being, subsequently, recycled.

The published works will be fully available in electronic format, in the website http://editora.unoesc.edu.br/index.php/roteiro.

Periodic Roteiro Focus Education

Editor Dra. Marilda Pasqual Schneider

Contactrroteiro@unoesc.edu.br

editora@unoesc.edu.br

(49) 35512065 
